\title{
When rare is just a matter of sampling: Unexpected dominance of clubtail dragonflies (Odonata, Gomphidae) through different collecting methods at Parque Nacional da Serra do Cipó, Minas Gerais State, Brazil
}

\author{
Marcus Vinícius Oliveira De Almeida ${ }^{1}$ Ângelo Parise Pinto ${ }^{1}$, Alcimar do Lago Carvalho ${ }^{1} \&$ Daniela Maeda Takiya ${ }^{2}$ \\ ${ }^{1}$ Laboratório de Biologia e Sistemática de Odonata (LABIOSIS), Departamento de Entomologia, Museu Nacional, Universidade Federal do Rio de \\ Janeiro, Quinta da Boa Vista s/n, São Cristóvão 20940-040 Rio de Janeiro-RJ, Brazil.mvoalmeida@gmail.com; odonata_angelo@hotmail.com; \\ alagoc@acd.ufrj.br \\ ${ }^{2}$ Laboratório de Entomologia, Departamento de Zoologia, Instituto de Biologia, Universidade Federal do Rio de Janeiro, Caixa Postal 68044, \\ 21941-971 Rio de Janeiro-RJ, Brazil. takiya@gmail.com
}

\begin{abstract}
When rare is just a matter of sampling: Unexpected dominance of clubtail dragonflies (Odonata, Gomphidae) through different collecting methods at Parque Nacional da Serra do Cipó, Minas Gerais State, Brazil. Capture of dragonfly adults during two short expeditions to Parque Nacional da Serra do Cipó, Minas Gerais State, using three distinct collecting methods - aerial nets, Malaise and light sheet traps - is reported. The results are outstanding due the high number of species of Gomphidae (7 out of 26 Odonata species), including a new species of Cyanogomphus Selys, 1873, obtained by two non-traditional collecting methods. Because active collecting with aerial nets is the standard approach for dragonfly inventories, we discuss some aspects of the use of traps, comparing our results with those in the literature, suggesting they should be used as complementary methods in faunistic studies. Furthermore, Zonophora campanulata annulata Belle, 1983 is recorded for the first time from Minas Gerais State and taxonomic notes about Phyllogomphoides regularis (Selys, 1873) and Progomphus complicatus Selys, 1854 are also given.
\end{abstract}

KEYWORDS. Anisoptera; Cerrado; Insecta; new record; taxonomy.

Dragonflies are important predators in freshwater communities (Corbet 1999) and are considered as model organisms for ecological and evolutionary research (Simaika \& Samways 2008). Adults stand out as skilled fliers, usually capturing prey in flight with the aid of excellent vision and raptorial legs (Corbet 1999). They are frequently collected through active capture using aerial nets, usually near sites used as rendezvous, venue where males and females meet as a direct prelude to copulation, and thus a spot with a concentration of individuals (Corbet 1999). Unlike active collecting, capturing adults with general insect traps is reported as ineffective and has rarely been used (Umar et al. 2012). However, some dragonflies are frequently "attracted" to certain artifacts that interfere with theirs visual perception, including reflective surfaces of cars (Pinhey 1966; Wildermuth \& Horváth 2005), solar panels, and even tombstones (Horváth et al. 2007). On the other hand, traps are used with success to passively capture specimens of other insect orders (Hosking 1979), among them two approaches stand out, the Malaise trap and different models of light traps.

Popular among entomologists, Malaise traps act as flight intercepts for winged insects (Matthews \& Matthews 1971) and they often capture species which are otherwise not usually obtained (Schauff 2012). In contrast, light traps attract crepuscular and nocturnal insects (and often diurnal individuals which were disturbed at night) using a luminous source with different wavelengths (Schauff 2012). In both methods, capture of dragonflies has been often reported, although specimens are collected in low numbers (e.g. Flint 1996; Johnson et al. 1995; Muzón \& Spinelli 1995).

Here we report an uncommon diversity of dragonflies collected using different methods at Parque Nacional da Serra do Cipó, Minas Gerais State, in the Brazilian Cerrado. Possible reasons for obtained results are given based on a review of the literature related to each collecting method. Furthermore a few taxonomic notes on captured Gomphidae (clubtails) are also given.

\section{MATERIAL AND METHODS}

Specimens were collected at Parque Nacional da Serra do Cipó (PNSC), which encompass part of Itambé do Mato Dentro, Jaboticatubas, Morro do Pilar, and Santana do Riacho municipalities, Minas Gerais State (Fig. 1), between December $9^{\text {th }}$ and $13^{\text {th }}$ of 2011 and March $2^{\text {th }}$ and $5^{\text {th }}$ of 2013. The region is an ecotone between Atlantic Forest and Cerrado biomes, the latter also known as Brazilian Savannah (see Madeira et al. 2008). Although there is no checklist for dragonflies from PNSC, and its assemblage was not intensively studied yet, or even considering invertebrates in general (Fig. 1; see also Madeira et al. 2008), PNSC has been visited regularly by collectors, consequently this park is the type-local- 
ity of several dragonfly taxa including Oxyagrion machadoi Costa, 1978, Peristicta janiceae Pessacq \& Costa, 2007, Zonophora campanulata machadoi St. Quentin, 1973, Rhionaeschna pauloi Machado, 1994, and Lauromacromia flaviae Machado, 2002 (St. Quentin 1973; Costa 1978; Pessacq \& Costa 2007; Machado 1994, 2002). Three sampling methods were used: (1) active, standard entomological aerial nets (hereafter AN) near temporary puddles along the trail to Bandeirinhas Canyon (approximately $19^{\circ} 24^{\prime} \mathrm{S}$, $43^{\circ} 34^{\prime} \mathrm{W}, 800 \mathrm{~m}$ a.s.1.), and trail to Gavião Waterfall (19²0’11"S, 4333’22"W, 839 m a.s.1.); (2) 6 meter-long Malaise trap (hereafter MT, Gressitt \& Gressitt 1962) crossing a water body (Fig. 2); and (3) light trap using a white sheet (hereafter LS, Schauff 2012) with 2 mixed mercury vapor lights (250W each) for nocturnal collecting; the last two on or near Córrego das Pedras stream $\left(19^{\circ} 22^{\prime} 17^{\prime \prime S}\right.$, $43^{\circ} 36^{\prime} 03^{\prime \prime W}, 766 \mathrm{~m}$ a.s.1.). Sampling effort was irregular, being of approximately one-day and one collector (eventual encounters during $6 \mathrm{~h}$ ) for the AN; five days (120 h) of MT; and two nights of LS ( $8 \mathrm{~h}$ ) in 2011; and approximately twodays and one collector ( $9 \mathrm{~h}$ ) for AN, four days (96 h) of MT, and one night of LS (4 h) in 2013. Complementarity indexes for different sampling methods were computed with $\mathrm{C}_{\mathrm{jk}}=\mathrm{U}_{\mathrm{jk} /} \mathrm{S}_{j k}$, where $\mathrm{U}_{\mathrm{jk}}$ is the number of unique species in both sites and $\mathrm{S}_{j k}$ total richness in both sites combined (Colwell \& Coddington 1994). All material is deposited in the Coleção Entomológica Prof. José Alfredo Pinheiro Dutra, Departamento de Zoologia, Instituto de Biologia, Universidade Federal do Rio do Janeiro (DZRJ; BCI http:// biocol.org/urn:1sid:biocol.org:col:35135), Rio de Janeiro, Brazil. Illustrations of the synthorax were made using a stereoscopic microscope equipped with a camera lucida; color pattern diagrams were based on the illustration of Progomphus formalis Belle, 1973 after the most recent revision of the genus (Belle 1973). Hind wing (Hw) length, in millimeters, was measured from the proximal end at RP\&RA to distal apex of the wing.

\section{RESULTS AND DISCUSSION}

A total of 115 specimens were collected, representing 26 species, 18 genera, and six families (Table I). The material from PNSC is rich when compared to other studies using insect traps, especially considering the short sampling period of only nine days (see Corbet 1981; Borisov 1990; Johnson et al. 1995; Muzón \& Spinelli 1995; Flint 1996; Askew et al. 1998; Glotzhober \& Riggs 1998; Sharma et al. 2000; Rizali et al. 2002; Borisov 2004; Richards \& Windsor 2007; Sartor et al. 2009; Umar et al. 2012). Gomphidae had the highest abundance, with 76 specimens (seven species), followed by Libellulidae with 19 specimens (eight species). Zygoptera specimens belonged to four families, Megapodagrionidae (three specimens and one species), Coenagrionidae (ten specimens and seven species), Protoneuridae (one specimen), and Calopterygidae (six specimens and two species). The most abundant species was Progomphus complicatus
Selys, 1854, with 50 specimens (31 males and 19 females), which was also the only species sampled using all three methods (Table I). The collected material is the first report of dragonflies using distinct sampling methods in PNSC, expanding our knowledge of dragonfly diversity in the poorly known Cerrado biome.

Table I. List of species of Odonata from Parque Nacional da Serra do Cipó, MG, Brazil (collected in December 2011 and March 2013) and number of specimens by collecting methods. Species with taxonomic remarks in the text are marked with an asterisk $(*)$.

\begin{tabular}{|c|c|c|c|c|}
\hline Family/Species & $\begin{array}{l}\text { Malaise } \\
\text { Trap }\end{array}$ & $\begin{array}{l}\text { Light } \\
\text { Sheet }\end{array}$ & $\begin{array}{l}\text { Aerial } \\
\text { Net }\end{array}$ & Total \\
\hline \multicolumn{5}{|l|}{ Megapodagrionidae } \\
\hline Heteragrion flavovittatum Selys, 1862 & - & $3 \mathrm{f}$ & - & 3 \\
\hline \multicolumn{5}{|l|}{ Coenagrionidae } \\
\hline Acanthagrion truncatum Selys, 1876 & $1 \mathrm{f}$ & - & $1 \mathrm{~m}$ & 2 \\
\hline Argia claussenii Selys, 1865 & - & - & $1 \mathrm{~m}, 2 \mathrm{f}$ & 3 \\
\hline Argia mollis Hagen in Selys, 1865 & - & - & $1 \mathrm{~m}$ & 1 \\
\hline Argia reclusa Selys, 1865 & $1 \mathrm{~m}$ & - & - & 1 \\
\hline Argia cf. sordida Hagen in Selys, 1865 & - & - & $1 \mathrm{~m}$ & 1 \\
\hline Argia sp. 1 & 1f & - & - & 1 \\
\hline Argia sp. 2 & $1 \mathrm{f}$ & - & - & 1 \\
\hline \multicolumn{5}{|l|}{ Protoneuridae } \\
\hline Epipleoneura metallica Rácenis, 1955 & $1 \mathrm{~m}$ & - & - & 1 \\
\hline \multicolumn{5}{|l|}{ Calopterygidae } \\
\hline Hetaerina rosea Selys, 1853 & $3 \mathrm{~m}, 2 \mathrm{f}$ & - & - & 5 \\
\hline $\begin{array}{l}\text { Mnesarete sp. [lacking S7-10; likely } M \text {. } \\
\text { gutifera (Selys, 1873)] }\end{array}$ & $1 \mathrm{~m}$ & - & - & 1 \\
\hline \multicolumn{5}{|l|}{ Gomphidae } \\
\hline Cacoides latro (Erichson, 1848) & - & $1 \mathrm{~m}$ & - & 1 \\
\hline Cyanogomphus sp. nov. & 1f & $1 \mathrm{~m}$ & - & 2 \\
\hline Gomphoides infumata (Rambur, 1842) & $6 \mathrm{~m}, 4 \mathrm{f}$ & $2 \mathrm{f}$ & - & 12 \\
\hline Phyllocycla viridipleuris (Calvert, 1909) & $6 f$ & 1f & - & 7 \\
\hline Phyllogomphoides regularis (Selys, 1873)* & $2 \mathrm{~m}$ & - & - & 2 \\
\hline Progomphus complicatus Selys, 1854* & $23 \mathrm{~m}, 17 \mathrm{f}$ & $7 \mathrm{~m}, 2 \mathrm{f}$ & $1 \mathrm{~m}$ & 50 \\
\hline $\begin{array}{l}\text { Zonophora campanulata annulata Belle, } \\
\text { 1983* }\end{array}$ & $2 \mathrm{~m}$ & - & - & 2 \\
\hline \multicolumn{5}{|l|}{ Libellulidae } \\
\hline Brechmorhoga nubecula (Rambur, 1842) & - & - & $1 \mathrm{~m}$ & 1 \\
\hline Brechmorhoga praedatrix Calvert, 1909 & $1 \mathrm{~m}, 1 \mathrm{f}$ & - & - & 2 \\
\hline Elga leptostyla Ris, 1909 & - & $1 \mathrm{~m}$ & - & 1 \\
\hline Erythrodiplax fusca (Rambur, 1842) & - & - & $7 \mathrm{~m}$ & 7 \\
\hline Macrothemis heteronycha (Calvert, 1909) & - & - & $1 \mathrm{f}$ & 1 \\
\hline Macrothemis imitans imitans Karsch, 1890 & - & - & $1 \mathrm{~m}, 1 \mathrm{f}$ & 2 \\
\hline Macrothemis cf. rupicola Rácenis, 1957 & - & - & $1 \mathrm{~m}$ & 1 \\
\hline Pantala flavescens (Fabricius, 1798) & - & - & $4 \mathrm{~m}$ & 4 \\
\hline Total & 74 & 18 & 23 & 115 \\
\hline
\end{tabular}

Dominance of Gomphidae. Clubtails, as with some species of other Odonata families, are strong flyers and often have secretive habits, which makes them hard to see in the field and they are consequently less frequently sampled using regular methods (such as AN), hence the high number of Gomphidae species obtained in both Malaise and light traps in PNSC is unusual. Past faunistic studies conducted at Cerrado and other Brazilian biomes have yielded no more than $5 \%$ of the total richness of adults for this family, which is usually dominated by Libellulidae, containing species that are largely abundant and common in the field (e.g. Machado 


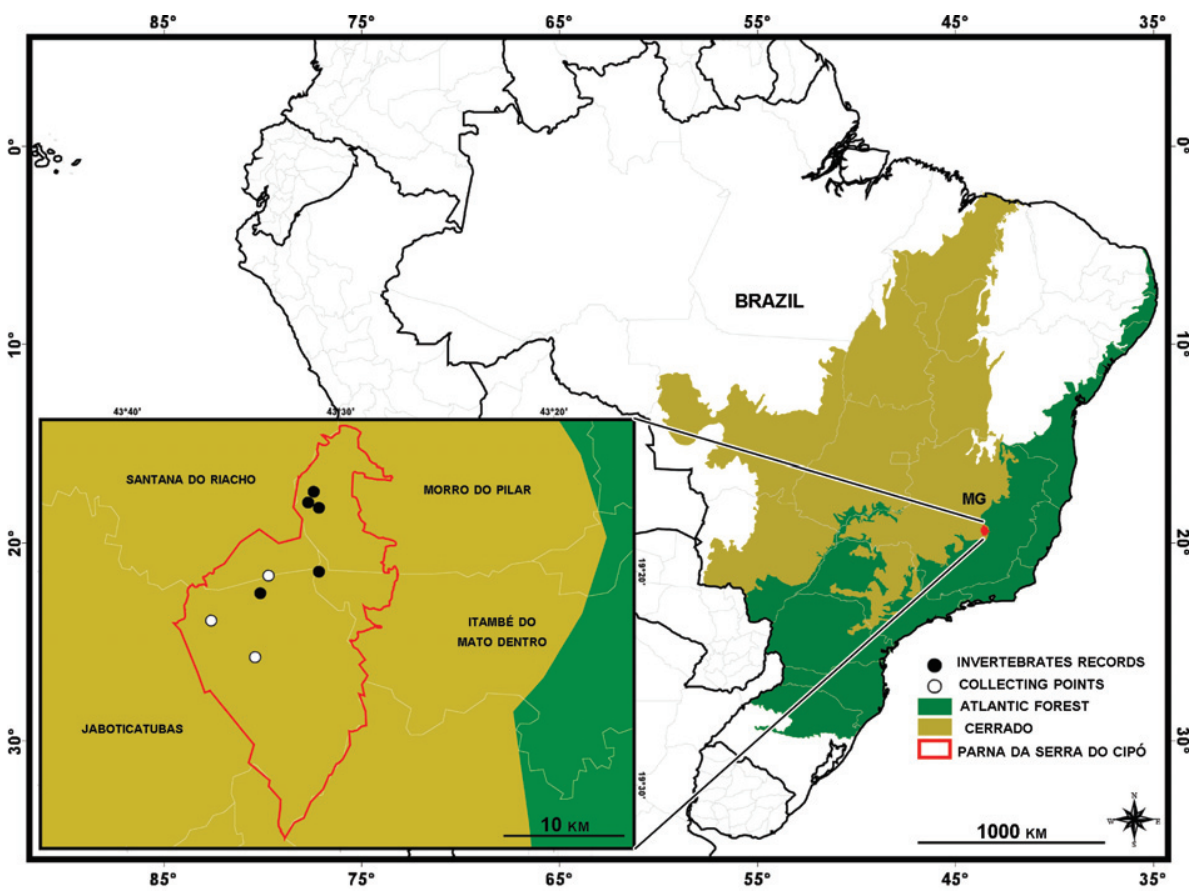

Fig. 1. Map of Brazil with inset showing in red boundaries of Parque Nacional da Serra do Cipó, Minas Gerais State (MG). White circles are collecting localities in this study and black circles are historical records for invertebrates reviewed by Madeira et al. (2008). Colored areas correspond to original extensions of Atlantic Forest (green) and Cerrado (brownish-yellow) biomes in Brazil (IBGE 2011).
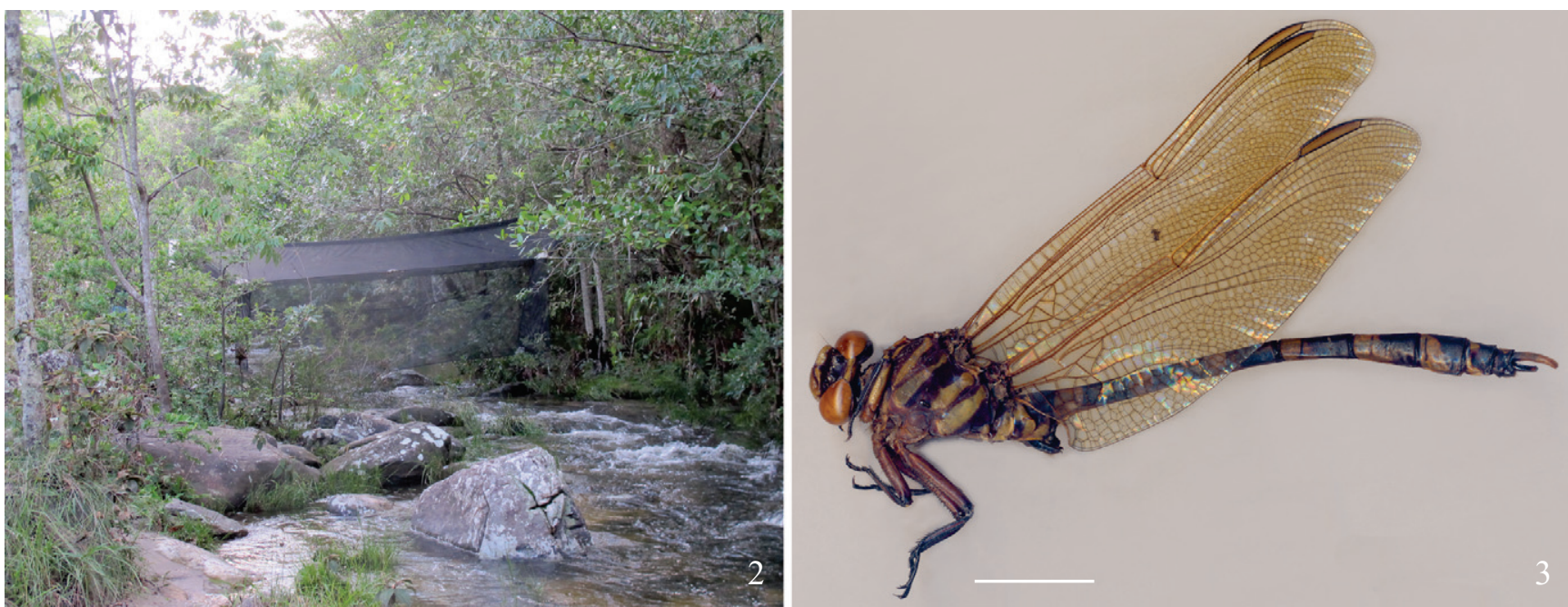

Figs. 2-3. Dragonflies from Parque Nacional da Serra do Cipó, Minas Gerais, Brazil. 2, Malaise trap crossing Córrego das Pedras (19²2’17"S, 43³6’03"W, $766 \mathrm{~m}$ a.s.1.); 3, Scanned image of a male of Zonophora campanulata annulata Belle, 1983 in lateral view. Scale bar: $10 \mathrm{~mm}$.

et al. 1991; Ferreira-Peruquetti \& Fonseca-Gessner 2003; Souza \& Costa 2006). The few studies where gomphids are in high relative numbers correspond to material reared from larvae in the laboratory (Louton et al. 1996; Dalzochio et al. 2011). Active captures of Gomphidae is usually so low that often none is recorded from a single site (e.g. Costa et al. 2001).

Comparison of methods. Published data on the collection of Odonata using light and Malaise traps are few, and their results cannot be easily compared, given that they were obtained in different regions, with quite distinct faunas and different collection techniques. PNSC yielded 74 specimens and 14 species using MT, followed by 23 specimens and 11 species using AN and 18 specimens and seven species using LS (Table I). The number of species obtained exclusively through MT was nine, LS three, and AN nine. Although sampling efforts were quite uneven, our data suggests high complementarities (sensu Colwell \& Coddington 1994) of the faunas collected by different methods: $\mathrm{C}_{\mathrm{MT}-\mathrm{AN}}=91 \% ; \mathrm{C}_{\mathrm{MT}}$ LS $=76 \%$; and $\mathrm{C}_{\text {LS-AN }}=94 \%$. 
Collecting dragonflies with AN is largely used as a standard approach for faunistic studies, however, it may not by entirely useful in obtaining reliable estimates of richness in some kinds of environments. Our study highlights that adopting other collecting methods in addition to AN allows obtaining species seldom captured using standard methods that may sometimes be considered rare (see Theischinger 2010). Thus, the high richness and abundance of Gomphidae using MT and LS likely would not have been obtained during same period using exclusively AN. Furthermore, collecting with AN is strongly biased because the collector chooses the target, which is evident when comparing the present results. Although the sampling effort using AN was lower and irregular, as expected male odonates were more strongly represented and some them pertaining to common and widespread species. The predominance of males and skewness in sampling using AN were discussed in detail by Paulson (1996), who considered the bright and attractive color of the males and their territorial behavior protecting the site of oviposition at rendezvous sites as the major factors related to this dominance, while females, generally less colorful and visiting oviposition sites only sporadically have a lower chance of being captured.

The location of the Malaise trap across the stream explains why only species that breed in lotic systems were captured and partially explains the high number of gomphids, typical of lotic environments. Glotzhober \& Riggs (1998, Fig. 4) suggested that a few modifications of the Townes MT (including enlargement of capture opening and recipient, and position) could yield differences in both quality of preservation and quantity of dragonflies sampled. Flint (1996) provided the most comprehensive work using MT with a prolonged sampling effort occurring over several years in the State of Virginia, USA. Flint (1996) recorded 171 specimens ( 87 damselflies and 84 true dragonflies) distributed among 48 species and 24 genera within nine families (i.e. Calopterygidae, Lestidae, Coenagrionidae, Petaluridae, Cordulegastridae, Aeshnidae, Gomphidae, Corduliidae, and Libellulidae). The familial composition is not unexpected, given that Libellulidae was the most abundant taxon, and Corduliidae and Gomphidae the rarest. In spite of the large sampling effort and high richness, which are rare in studies using this trap, Flint's (1996) results show a comparatively smaller number of specimens compared to other methods like AN used during same period, and mirrors similar studies where the capture of dragonflies was considered accidental (Johnson et al. 1995; Muzón \& Spinelli 1995; Askew et al. 1998; Rizali et al. 2002; Richards \& Windsor 2007; Sartor et al. 2009). An exception is Glotzhober \& Riggs (1998), who focused on the biology of Cordulegaster erronea Hagen in Selys, 1878, in which a modified Townes MT sampled a total of 142 specimens during only two summer seasons with irregular numbers of days and traps.

Light traps are not usually used as a sampling method for dragonflies (Umar et al. 2012) and there are few studies focusing in adults (e.g. Borisov 1990; Sharma et al. 2000). Corbet
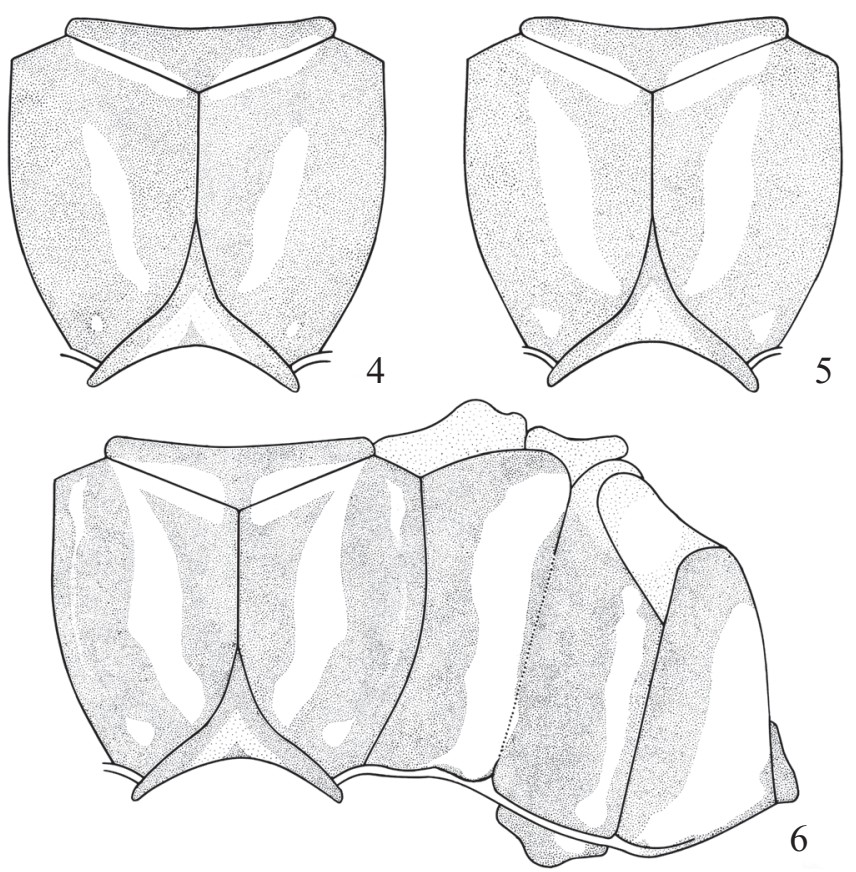

Figs. 4-6. Diagrammatic representation of the color pattern of the male synthorax of Progomphus complicatus Selys, 1854. 4-5, mesepisternum in dorsal view of specimens from Angra dos Reis, Rio de Janeiro, Brazil (4) and Parque Nacional da Serra do Cipó, Minas Gerais, Brazil (5); 6, synthorax of another specimen from Parque Nacional da Serra do Cipó.

(1981) suggests that light traps could be important to phenological and ecological studies of Anisoptera. Nevertheless, captures using LS in PNSC were likely accidental and could have occurred due to perturbation of diurnal odonates on their surrounding resting area. Recently Umar et al. (2012) provided an extensive account on the use of light traps for sampling dragonflies and discussed the possible causes of light attraction and future directions to investigate this phenomenon. They recognized two groups of species attracted by artificial luminous sources (photoxenes), i.e. obligatory and facultative. Based on Borisov's (2007 apud Umar et al. 2012) scheme, obligatory photoxenes are classified in three types: (1) individuals that stay active until night during moving behavior searching for sites to forage, rest, or copulate in warm periods of year; (2) teneral individuals that emerged at night; and (3) teneral individuals of diurnal species that are active under high temperatures, low humidity, and direct sunlight. The major reason for individuals to arrive at these light sources is night emergence (type 2), which prevents tenerals from desiccation and predators (Borisov 2004), and light sources may indicate open areas for diurnal dragonflies (Mazokhin-Porshnjakov 1960), thus they are not really attracted but confused (Umar et al. 2012). However, these captures are probably related to several factors depending on species behavior and preferences, and since the species 'attracted' to LS in our study are almost all represented by mature individuals and not by tenerals, thus negating Borisov' (2004) type 2 in interpreting our results. Since no crepuscular species was captured using LS in PNSC captures using this method were likely accidental and may have 
occurred due to perturbation of odonates on their surrounding resting area.

Taxonomic notes on Gomphidae. Of particular interest among the material is the first record of the rare Zonophora campanulata annulata Belle, 1983 from Minas Gerais State, and of a new species of Cyanogomphus Selys, 1873, which will be described elsewhere. We also provide below some taxonomic notes on some of the collected club-tailed dragonflies.

The campanulata-group of Zonophora Selys, 1854 was proposed by Belle (1983) to include Zonophora diversa Belle, 1983 (recorded from Argentina, Paraguay, and Santa Catarina State, Brazil) and the three Brazilian subspecies of Zonophora campanulata (Burmeister, 1839), all of them with allopatric distributions. The nominotypical subspecies Zonophora campanulata campanulata (Burmeister, 1839) is apparently restricted to the Atlantic Forest with reliable records from Espírito Santo, Rio de Janeiro, Minas Gerais, and São Paulo States (Schmidt 1941; Belle 1983; Garrison et al. 2006), while Zonophora campanulata machadoi St. Quentin, 1973 is known from four localities at the transition between Cerrado and Atlantic Forest in eastern Minas Gerais State (St. Quentin 1973; Belle 1983, 1992) and Z. c. annulata only known from its typelocality, municipality of Jataí, Goiás State (Belle 1983). There are also unconfirmed records and records without subspecies identification, from Goiás (Schmidt 1941) and Paraná (Heckman 2006) States in Brazil, Suriname, and Guyana (Belle 1983). While these last two records are probably due to errors in Martin's labels (see Belle 1983), the one from Goiás, in the Brazilian Cerrado, very likely refers to any of the nonnominotypical subspecies. The three subspecies are recognized solely by differences in color pattern because other structures appear not to vary (Belle 1983: 169). The new record from Minas Gerais of Z. c. annulata shown here is intriguing, since the Serra do Cipó corresponds to the type-locality of $Z$. $c$. machadoi. This sympatric distribution indicates that these entities may represent either distinct species or color variants within a polymorphic species. Further collections and studies would be needed to test these hypotheses.

The taxonomic history of Progomphus complicatus is somewhat confusing. The species was described by Selys (1854) in his "Synopsis des Gomphines" without reference to the number of studied specimens or any type designation. The possibly correct number of specimens was only clarified in Selys \& Hagen (1858), where the species was redescribed and three males were cited, one from Brazil, deposited at the Museum of Vienna (Naturhistorisches Museum Wien), a second collected by "Dr [Peter] Clausen", without collection data, and a third one from Bahia State, Brazil, the last two deposited in the collection of Baron Michel Edmond de Sélys-Longchamps (currently in the Institut Royal des Sciences Naturelles de Belgique, Brussels). These three specimens were recognized by Belle (1973) as the type series and he designated the male collected by Peter Clausen as the lectotype. Although this specimen lacks any kind of locality data other than "Brazil", it was very likely collected in Minas Gerais, where Clausen lived during the 1830's and is apparently the sole origin of all material of his entomological collection, which was later sold to the Muséum $\mathrm{Na}$ tional d'Histoire Naturelle, Paris (Papavero 1971: 91). This conclusion can be extended to the remaining specimens collected by Peter Clausen for which there is no mention of any specific locality, since in addition to his itinerary described in Papavero (1971), several labels of his material make direct reference to Minas Gerais, such as to the type series of Argia claussenii Selys, 1865 (see Selys 1865).

Selys's (Selys 1854; Selys \& Hagen 1858) descriptions of the thoracic pattern colors of $P$. complicatus are short, and concern only to the shape of synthoracic first antehumeral stripe, as to whether it is or is not connected to the mesothoracic collar, and, in some cases assumes the shape of " $u n 7 \mathrm{de}$ chaque côté" (Selys \& Hagen 1858). Variations of synthorax color and size were both cited by Selys $(1869 ; 1873)$, followed by Ris (1911), all of whom highlighted the great variation in the extension of pale stripes and in its size related to sexual dimorphism. Ris (1911) was the first to provide illustrations depicting the color pattern of the synthorax, based on specimens from Brazil (States of Espírito Santo and Rio de Janeiro) and Paraguay (San Bernardino), those from the last locality, with larger extension of pale stripes, however none of these exhibited mesothoracic collar connected to the first pale antehumeral stripe. In addition, Belle (1973) stated that females from Parque Nacional da Tijuca, already cited by Selys (1873), are the largest, and males from Paraguay cited by Ris (1911) the smallest. All of the variation cited above precludes a correct identification of the species using the keys by Belle (1973) and St. Quentin (1973), because they only allow to key out specimens of $P$. complicatus with the first antehumeral stripes separated from the mesothoracic collar. However, Belle (1994) recognized the variation previously mentioned by Selys \& Hagen (1858) and in his key exclusively to Brazilian species, $P$. complicatus keys out twice, one for specimens with antehumeral stripes connected to collar and another for those unconnected. Heckman's (2006) key is dubious since it merged the two possibilities in one couplet and should be avoided. Few authors acknowledged these variations in their respective taxonomic keys, thus generating doubts as to the species identification.

The material of $P$. complicatus from PNSC shows great variation both in size and the color pattern of synthorax (Figs. 5-6), mainly in regard to the antehumeral stripes and mesothoracic collar, aspects that brought us to study this species more extensively, inspecting the literature, as well as the material of the species deposited at DZRJ and CZMA (Universidade Federal do Maranhão, Brazil) collections. A total of 80 specimens were examined from the following Brazilian States: Ceará (2m), Rio de Janeiro (18m, 2f), São Paulo (1m), Minas Gerais (33m, 21f), Santa Catarina (1m), and Rio Grande do Sul (2m), which corresponds to the largest series examined of this species. We identified three major color patterns on the synthorax ranging from darker specimens with less extensive pale stripes to paler specimens with numerous, well-defined, and extensive pale stripes, as 
follows: (A) first antehumeral stripe distinct short and not connected to collar; second antehumeral stripe poorly defined or reduced posteriorly to a small rounded spot close to the antealar sinus; metepisternal stripe absent or barely defined (Fig. 4); (B) first antehumeral stripe long and extending anteriorly close to collar; second antehumeral stripe as in (A), however, in a few cases long and clearly defined; metepisternal stripe poorly or clearly defined (Fig. 5); and (C) first antehumeral stripe long and largely connected to pale area of mesothoracic collar; second antehumeral stripe long and almost defined along its extension; metepisternal stripe clearly defined (Fig. 6). Pattern (A) was the most common, occurring in 70 specimens (88\%), type (B) less common in nine specimens $(11 \%)$, and finally the type $(\mathrm{C})$, with only one specimen (1\%). The population from PNSC showed all patterns A-C (Figs. 4-6), while out of 20 examined specimens from Rio de Janeiro only a single one exhibited the type (B), with the remainder exhibiting pattern (A). Size range measurements for both sexes agrees with the range recorded in the literature, however, the hind wing of specimens from Rio de Janeiro was noticeably longer than those from other States with 24.5-29.2 $\mathrm{mm}($ mean $=26.5)$ and $22.4-25.9 \mathrm{~mm}$ (mean $=24.9)$, respectively.

Our two male specimens of Phyllogomphoides regularis (Selys, 1873) were easily keyed to that species in Belle (1984). However, we noted differences, especially in size and color pattern, with a male from Rio Grande do Sul State, Brazil (São Francisco de Paula, Parque Nacional de Aparados da Serra) deposited at Museu Nacional, Universidade Federal do Rio de Janeiro, which was identified by Jean Belle as this species. Some of these aspects were already mentioned by Belle (1970, 1984) who correctly assumed that this variation was not ontogenetic (specimen maturity). The two males from Serra do Cipó are in general paler than the male from Rio Grande do Sul, and other differences are (characters of specimen from southern Brazil in parentheses): femora yellowish-brown with distinctive dark-brown to black longitudinal stripes (entirely yellowish-brown); articulations of femur-tibia with large pale yellowish areas (entirely black); dorsal surface of tibiae yellow (black); anterior surface of costal margin yellow, ventral surface after nodus entirely yellow (anterior margin with an inconspicuous yellow line); caudal appendages darker, epiproct dark-brown to black (yellowish); cercus with distinct dorsal black areas (almost entirely yellowish-brown); and cercus distinctly thinner and with dorsal process (tooth) slightly more distal than those from Rio Grande do Sul and Santa Catarina States, the latter illustrated by Belle (1970). Further studies may prove that southern and northern populations correspond to distinct sibling species.

\section{ACKNOWLEDGEMENTS}

We are thankful to entomologist colleagues Alan P. M. Santos, Ana L. Henriques-Oliveira, Beatriz M. Camisão, Brunno H. L. Sampaio (DZRJ), Marcela L. Monné (MNRJ), and Rodney R. Cavichioli (UFPR), who accompanied DMT in the field's expedition and captured this noteworthy material. To ICMBIO/SISBIO for collecting licenses numbers 14591-8 and 23620-6. This study was partially supported by CNPq (PIBIC-UFRJ fellowship to first author (process 151840/2012-1) and postdoctoral fellowship to APP (process 151122/2013-0)).

\section{REFERENCES}

Askew, R.R., Prosser, R. \& Corbet, P.S. 1998. Odonata of the Cayman Islands: a review. Bulletin of American Odonatology 5: 27-32.

Belle, J. 1970. Studies on South American Gomphidae (Odonata) with special reference to the species from Surinam. Studies on the fauna of Suriname and other Guyanas (43) 11: 1-158, pls. i-xxi.

Belle, J. 1973. A revision of the New World genus Progomphus Selys, 1854 (Anisoptera: Gomphidae). Odonatologica 2: 191-308.

Belle, J. 1983. A review of the genus Zonophora Selys (Odonata, Gomphidae). Tijdschrift voor Entomologie 126: 145-173.

Belle, J. 1984. A synopsis of the South American species of Phyllogomphoides, with a key and descriptions of three new taxa (Odonata, Gomphidae). Tijdschrift voor Entomologie 127: 79-100.

Belle, J. 1992. Studies on ultimate instar larvae of neotropical Gomphidae, with the description of Tibiagomphus gen. nov. (Anisoptera). Odonatologica 21: 1-24.

Belle, J. 1994. On five species of Progomphus Selys from Brazil with the descriptions of four new taxa (Odonata: Gomphidae). Zoologische Mededelingen 68: 203-214.

Borisov, S. 1990. On flight of Odonata to artificial light sources. Zoologicheskii Zhurnal 69: 29-35.

Borisov, S. 2004. The night emergence of dragonflies (Odonata) in temperate latitudes of West Asia. Siberian Journal of Ecology 4: 449-455.

Colwell, R.K. \& Coddington, J.A. 1994. Estimating terrestrial biodiversity through extrapolation. Philosophical Transactions of the Royal Society B 345: 101-118.

Corbet, P.S. 1981. Seasonal incidence of Anisoptera in light-traps in Trinidad, West Indies. Odonatologica 10: 179-187.

Corbet, P.S. 1999. Dragonflies: behavior and ecology of Odonata. Ithaca, Cornell University Press, xxxii+829 p.

Costa, J.M. 1978. Revisão do gênero Oxyagrion Selys, 1876 (Odonata, Coenagrionidae). Publicações Avulsas do Museu Nacional 61: $\mathrm{x}+1-$ 216, pls. i-xxxix.

Costa, J.M., Lourenço, A.N. \& Vieira, L.P. 2001. Odonatos coletados no Parque Ecológico Municipal Chico Mendes (Unidade de Conservação Ambiental), Rio de Janeiro, Brasil. Entomologia y Vectores 8: 431-448.

Dalzochio, M.S., Costa, J.M. \& Uchôa, M.A. 2011. Diversity of Odonata (Insecta) in lotic systems from Serra da Bodoquena, Mato Grosso do Sul State, Brazil. Revista Brasileira de Entomologia 55: 88-94.

Ferreira-Peruquetti, P.S. \& Fonseca-Gessner, A.A. 2003. Comunidade de Odonata (Insecta) em áreas naturais de Cerrado e monocultura no nordeste do Estado de São Paulo, Brasil: relação entre o uso do solo e a riqueza faunística. Revista Brasileira de Zoologia 20: 219-224.

Flint, O.S. 1996. Odonata taken in Malaise Traps, with special reference to Virginia. Banisteria 8: 37-43.

Garrison, R.W., von Ellenrieder, N. \& Louton, J.A. 2006. Dragonfly genera of the New World: an illustrated and annotated key to the Anisoptera. Baltimore, The Johns Hopkins University Press, xiv +368 p.

Glotzhober, R.C. \& Riggs, D. 1998. Adapting the Townes Malaise trap for collecting live Odonata. Bulletin of American Odonatology 5: 43-48.

Gressitt, J.L., \& Gressitt, M.K. 1962. An improved malaise trap. Pacific Insects 87: 87-90.

Heckman, C.W. 2006. Encyclopedia of South American aquatic insects: Odonata - Anisoptera. Illustrated keys to known families, genera, and species in South America. Dordrecht, Springer, viii+725 p.

Horváth, G., Malik, P., Kriska, G. \& Wildermuth, H. 2007. Ecological traps for dragonflies in a cemetery: the attraction of Sympetrum species 
(Odonata: Libellulidae) by horizontally polarizing black gravestones. Freshwater Biology 52: 1700-1709.

Hosking, G.P. 1979. Trap comparison in the capture of flying Coleoptera. New Zealand Entomologist 7: 87-92.

Instituto Brasileiro de Geografia e Estatística (IBGE). 2011. Geociências. Mapas Interativos, Biomas. Available at: ftp://geoftp.ibge.gov.br/ mapas_interativos/biomas.zip (accessed 21 November 2011).

Johnson N.F., Kovarik, P.W. \& Glotzhober, R.C. 1995. Dragonflies in Malaise traps. Argia 7: 21-22.

Louton, J.A., Garrison, R.W. \& Flint, O.S. 1996. The Odonata of Parque Nacional Manu, Madre de Dios, Peru: natural history, species richness and comparisons with other neotropical sites, p. 431-449. In: Wilson, D.E. \& Sandoval, A. (eds.). Manu: The Biodiversity of Southeastern Peru. Washington, D. C., Smithsonian Institution Press, 679 p.

Machado, A.B.M. 1994. Aeshna (Hesperaeschna) pauloi spec. nov. from mountain streams in Brazil (Anisoptera: Aeshnidae). Odonatologica 23: $159-168$.

Machado, A.B.M. 2002. Description of Lauromacromia flaviae spec. nov., with notes on the holotype of L. luismoojeni (Santos) (Anisoptera: Corduliidae). Odonatologica 31: 313-318.

Machado, A.B.M., Mesquita, H.G. \& Machado, P.A.R. 1991. Contribuição ao conhecimento dos odonatos da Estação Ecológica de Maracá - Roraima. Acta Amazonica 21: 159-173.

Madeira, J.A., Ribeiro, K.T., Oliveira, M.J.R., Nascimento, J.S. \& Paiva, C.L. 2008. Distribuição espacial do esforço de pesquisa biológica na Serra do Cipó, Minas Gerais: subsídios ao manejo das unidades de conservação da região. Megadiversidade 4: 255-269.

Matthews, R.W. \& Matthews, J.R. 1971. The Malaise trap: its utility and potential for sampling insect populations. Michigan Entomologist 4: 117-122.

Mazokhin-Porshnjakov, G.A. 1960. Why insects fly to light by night. Revue d'Entomologie de l'URSS 39: 52-58.

Muzón, J. \& Spinelli, G.R. 1995. Patagonian Odonata in Malaise trap. Argia 7: 22-23.

Papavero, N. 1971. Essays on the history of Neotropical dipterology, with special reference to collectors (1750-1905). Vol. I. São Paulo, Museu de Zoologia, Universidade de São Paulo, vii+216 p.

Paulson, D.R. 1996. Sexism and Odonata conservation. Argia 8: 31-34.

Pessacq, P. \& Costa, J.M. 2007. Three new species of Peristicta Hagen in Selys (Odonata: Zygoptera: Protoneuridae) from Brazil. Neotropical Entomology 36: 46-52.

Pinhey, E. 1966. Notes on African Odonata, particularly type material. Revue de Zoologie et de Botanique Africaines 73: 283-308.

Richards, L.A. \& Windsor, D.M. 2007. Seasonal variation of arthropod abundance in gaps and the understorey of a lowland moist forest in Panama. Journal of Tropical Ecology 23: 169-176.

Ris, F. 1911. Über einige Gomphinen von Südbrasilien und Argentina. Memoires de la Société Entomologique de Belgique 19: 101-119.

Rizali, A., Buchori, D. \& Triwidodo, H. 2002. Insect diversity at the forest margin-rice field interface: indicator for a healthy ecosystem. Hayati 9: $41-48$.

Sartor, V., Woldan, D.R.H. \& Garcia, F.R.M. 2009. Inventário e aspectos ecológicos da fauna entomológica no município de União da Vitória Paraná. Biodiversidade Pampeana 7: 35-43.

Schauff, M.E. 2012. Collecting and preserving insects and mites: techniques and tools. Available at: http://www.ars.usda.gov/SP2UserFiles/ad_hoc/ 12754100CollectingandPreservingInsectsandMites/collpres.pdf (accessed 29 November 2012). [Updated electronic version of Steyskal, G.C., Murphy, W.L. \& Hoover, E.M. 1986. USDA Miscellaneous Publication n. 1443]

Schmidt, E. 1941. Revision der Gattung Zonophora Selys (Odonata Gomphidae neotrop.). Deutsche Entomologische Zeitschrift 1/2: 76-96.

Selys-Longchamps, M.E. de. 1854. Synopsis des Gomphines. Bulletins de l'Académie Royale des Sciences, des Lettres et des Beaux-Arts de Belgique (1 ${ }^{\mathrm{e}}$ série) 21 ( $2^{\mathrm{e}}$ partie): $23-112$.

Selys-Longchamps, M.E. de. 1865. Synopsis des Agrionines, 5me légion: Agrion. Bulletins de l'Académie Royale des Sciences, des Lettres et des Beaux-Arts de Belgique (2 $2^{\mathrm{e}}$ série) 20: 375-417.

Selys-Longchamps, M.E. de. 1869. Secondes additions au synopsis des Gomphines. Bulletins de l'Académie Royale des Sciences, des Lettres et des Beaux-Arts de Belgique (2 ${ }^{\mathrm{e}}$ série) 28: 168-208.

Selys-Longchamps, M.E. de. 1873. Troisièmes additions au synopsis des Gomphines. Bulletins de l'Académie Royale des Sciences, des Lettres et des Beaux-Arts de Belgique (2 ${ }^{\mathrm{e}}$ série) 35: 732-774.

Selys-Longchamps, M.E. de \& Hagen, H.A. 1858. Monographie des Gomphines. Mémoires de la Société Royale des Sciences de Liège 11: 257-713, pls 1-23.

Sharma, R.M, Talmale, S.S. \& Kulkarni, P.P. 2000. Odonates attracted to light at Tadoba-Andhari Tiger Reserve, Maharashtra. Bionotes 2: 13.

Simaika, J.P. \& Samways, M.J. 2008. Valuing dragonflies as service providers, p. 109-123. In: Córdoba-Aguilar, A. (ed.). Dragonflies and damselflies: study models in ecological and evolutionary research. Oxford, Oxford University Press, xii+190 p.

Souza, L.O.I. \& Costa, J.M. 2006. Inventário da Odonatofauna no Complexo Aporé-Sucuriú: área prioritária 316-Jauru, p. 79-88, 225-233. In: Pagotto, T.C.S. \& Souza, P.R. (Orgs.). Biodiversidade do Complexo Aporé-Sucuriú: subsídios à conservação e manejo do bioma Cerrado. Campo Grande, Editora UFMS, 308 p.

St. Quentin, D. 1973. Die Gomphidenfauna Südamerikas (Ordn.: Odonata). Annalen des Naturhistorischen Museums in Wien 77: 335-363.

Theischinger, G. 2010. Der GSI-Clade (Odonata, Libelluloidea) in Australien - Systematik im Fluss. Entomologica Austriaca 17: 49-66.

Umar, D.M., Marinov, M.G., Schorr, M. \& Chapman, H.M. 2012. Odonata attracted by light - a new topic for myth-busters. International Dragonfly Fund - Report 43: 1-52.

Wildermuth, H. \& Horváth, G. 2005. Visual deception of a male Libellula depressa by the shiny surface of a parked car (Odonata: Libellulidae). International Journal of Odonatology 8: 97-105.

Received 19 July 2013; 16 November 2013

Associate Editor: Eduardo Domínguez 